Editorial

\title{
Announcement: Remote Sensing 2017 Best Guest Editor Award
}

\section{Remote Sensing Editorial Office}

Multidisciplinary Digital Publishing Institute, Alban-Anlage 66, 4052 Basel, Switzerland; remotesensing@mdpi.com

Received: 30 January 2018; Accepted: 4 February 2018; Published: 5 February 2018

Guest Editors help invite many high-quality papers for Remote Sensing. To acknowledge and encourage the generous work and precious time of the guest editor team of Special Issues in Remote Sensing, we launched the Best Guest Editor Award last year for Special Issues closed from 1 June 2016 to 31 June 2017.

In total, 40 Special Issues were closed from 1 June 2016 to 31 June 2017 and these Special Issues contributed 607 papers, with an average of 15 papers per Special Issue. A particular highlight was the Special Issue titled "Earth Observations for Geohazards" [1] edited by Prof. Zhenhong Li and Prof. Roberto Tomas. This Special Issue covered innovative Earth Observations methods and applications for monitoring and modeling geohazards. There were 44 papers [2-45] published in it. All of the publications in this Special Issue were cited and they contributed a total of 203 citations for the journal by the end of 2017. The paper focused on imaging land subsidence induced by groundwater extraction using radar interferometry [2] was highly cited, with 16 citations by the end of 2017.

We are greatly excited to announce the winners: Prof. Dr. Zhenhong Li (Newcastle University, UK) and Prof. Roberto Tomas (University of Alicante, Spain) (Figure 1).

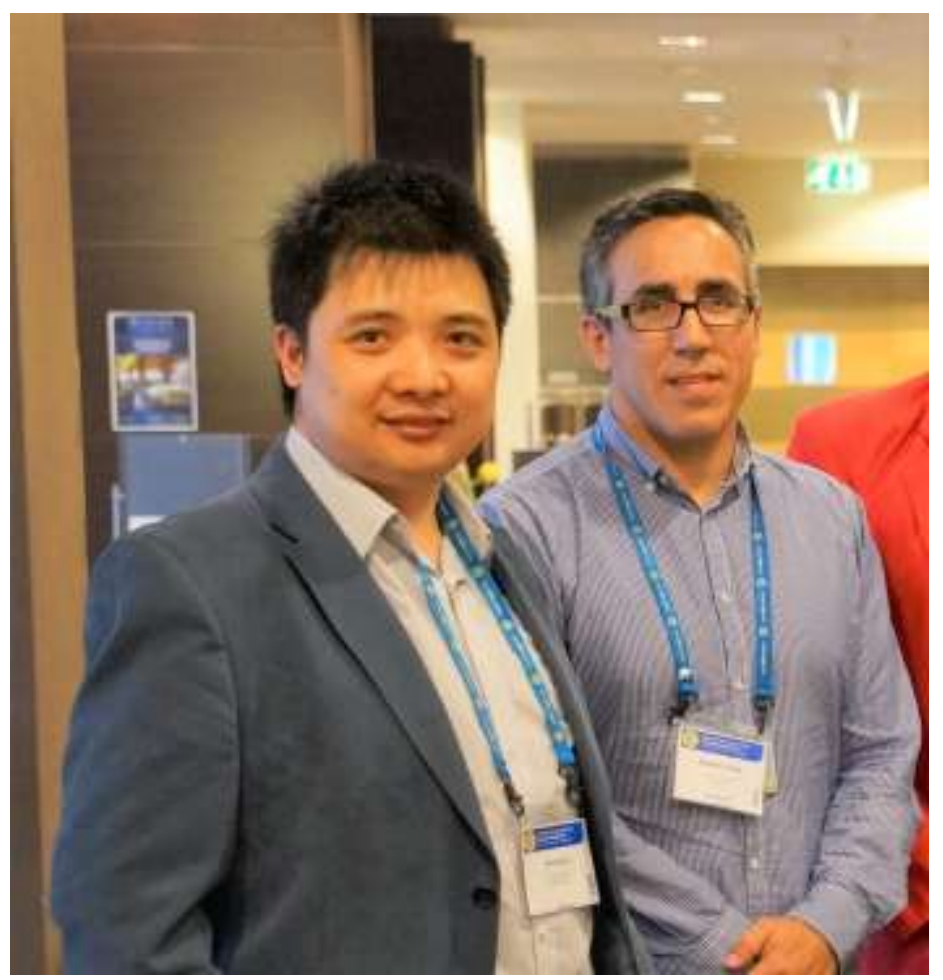

Figure 1. Prof. Dr. Zhenhong Li and Prof. Roberto Tomas at EGU 2011. 
Prof. Dr. Zhenhong Li is Chair Professor of Imaging Geodesy in the School of Engineering at Newcastle University. He received a BSc degree (with distinction) in geodesy from Wuhan Technical University of Surveying and Mapping (now Wuhan University), Wuhan, China, in 1997, and a Ph.D. degree in GPS, geodesy, and navigation from University College London, London, UK, in 2005. Professor Li has approximately twenty years of research experience in Space Geodesy and Remote Sensing (mainly SAR, InSAR, and GNSS) and their application to geohazards (e.g., earthquakes, landslides, and land subsidence), infrastructure stability, and precision agriculture. He specializes in the development of InSAR atmospheric corrections and time-series algorithms for precisely mapping surface movements, and has made several original contributions to the direct estimation and/or mitigation of atmospheric effects on InSAR measurements. His recent major achievements include: (i) the generation of the first interferogram from the Chinese Gaofen-3 mission together with some collaborators, which is also the first interferogram from Chinese civilian radar missions; and (ii) the release of the Generic Atmospheric Correction Online Service for InSAR (GACOS). He has investigated a series of large earthquakes (e.g., Sumatra (Indonesia, 2007), Wenchuan (China, 2008), Yushu (China, 2010), Van (Turkey, 2011), Tohoku (Japan, 2011), and Gorkha (Nepal, 2015)) and active landslides (e.g., Huangtupo, Shuping, and Daguangbao landslides, China). Being the lead PI of STFC Newton Agri-Tech PAFiC project, he is also an investigator of the Centre for the Observation and Modelling of Earthquakes, Volcanoes, and Tectonics (COMET), the consortium Looking Inside the Continents from Space (LICS), and the CBDRRiC project within IRNHiC.

Prof. Roberto Tomas is full professor in geotechnical engineering at the Department of Civil Engineering in the University of Alicante (UA), Spain. He received the Master's degrees in Civil Engineering and Geological Engineering and his Ph.D. in Engineering Geology in the UA. He was awarded the National Graduation Award for Higher University Education for his Master's study and the Extraordinary Ph.D. Award for his Ph.D. research, respectively.

He is UA-based Director of the Associate Research Unit IGME-UA of ground movements monitoring using radar interferometry (UNIRAD), leader of the Geotechnical and Structural Engineering (INTERES) research group, and is a collaborator of the Geohazards InSAR laboratory and Modelling Group of the IGME. He is also member of the UNESCO Working Group on Land Subsidence and coordinator of the Spanish Working Group on land subsidence.

His main research is in the field of the application of remote sensing techniques for monitoring and modelling of natural hazards (with emphasis in landslides and land subsidence) and infrastructures, as well as for rock mass characterization. He has investigated InSAR land subsidence in the Vega Baja and Media of the Segura River (Spain), the Guadalentín Valley (Spain), Madrid (Spain), and Beijing (China), and landslides such as Aitana deep seat (Spain), Huangtupo (China), and Daguangbao (China).

Since 2011, he has been a visiting scientist at the University of Glasgow (UK), Newcastle University (UK), Escuela Superior Politécnica del Litoral (Ecuador), and Universidade do Minho (Portugal). Additionally, he was recently granted an international research-fellowship to spend three months at the University of Florence (Italy) in 2018.

He has led or been involved in more than 40 national and international research projects, as well as over 50 research contracts with companies. He is a reviewer of more than 30 international journals and conferences, and a member of the editorial boards of several international scientific journals. Furthermore, he is the author of more than 80 scientific articles (53 in SCI) and more than 150 proceedings and book chapters. He has successfully supervised six Ph.D. Theses. For more detailed information, visit: personal.ua.es/en/roberto-tomas.

On behalf of the Remote Sensing editorial board members and editorial staffs, we wish to congratulate the two outstanding Guest Editors for their accomplishments.

Conflicts of Interest: The authors declare no conflicts of interest. 


\section{References}

1. Special Issue "Earth Observations for Geohazards". Available online: http:/ /www.mdpi.com/journal/ remotesensing/special_issues/earth_geohazards (accessed on 23 January 2018).

2. Chen, M.; Tomás, R.; Li, Z.; Motagh, M.; Li, T.; Hu, L.; Gong, H.; Li, X.; Yu, J.; Gong, X. Imaging Land Subsidence Induced by Groundwater Extraction in Beijing (China) Using Satellite Radar Interferometry. Remote Sens. 2016, 8, 468. [CrossRef]

3. Chen, K.; Zamora, N.; Babeyko, A.; Li, X.; Ge, M. Precise Positioning of BDS, BDS/GPS: Implications for Tsunami Early Warning in South China Sea. Remote Sens. 2015, 7, 15955-15968. [CrossRef]

4. Cianflone, G.; Tolomei, C.; Brunori, C.; Dominici, R. InSAR Time Series Analysis of Natural and Anthropogenic Coastal Plain Subsidence: The Case of Sibari (Southern Italy). Remote Sens. 2015. [CrossRef]

5. Kropáček, J.; Vařilová, Z.; Baroň, I.; Bhattacharya, A.; Eberle, J.; Hochschild, V. Remote Sensing for Characterisation and Kinematic Analysis of Large Slope Failures: Debre Sina Landslide, Main Ethiopian Rift Escarpment. Remote Sens. 2015. [CrossRef]

6. Pacheco-Martínez, J.; Cabral-Cano, E.; Wdowinski, S.; Hernández-Marín, M.; Ortiz-Lozano, J.; Zermeño-de-León, M. Application of InSAR and Gravimetry for Land Subsidence Hazard Zoning in Aguascalientes, Mexico. Remote Sens. 2015. [CrossRef]

7. Al-Rawabdeh, A.; He, F.; Moussa, A.; El-Sheimy, N.; Habib, A. Using an Unmanned Aerial Vehicle-Based Digital Imaging System to Derive a 3D Point Cloud for Landslide Scarp Recognition. Remote Sens. 2016, 95. [CrossRef]

8. Zhai, W.; Shen, H.; Huang, C.; Pei, W. Building Earthquake Damage Information Extraction from a Single Post-Earthquake PolSAR Image. Remote Sens. 2016, 171. [CrossRef]

9. Jiang, Y.; Liao, M.; Zhou, Z.; Shi, X.; Zhang, L.; Balz, T. Landslide Deformation Analysis by Coupling Deformation Time Series from SAR Data with Hydrological Factors through Data Assimilation. Remote Sens. 2016, 179. [CrossRef]

10. He, M.; Zhu, Q.; Du, Z.; Hu, H.; Ding, Y.; Chen, M. A 3D Shape Descriptor Based on Contour Clusters for Damaged Roof Detection Using Airborne LiDAR Point Clouds. Remote Sens. 2016, 189. [CrossRef]

11. Hu, J.; Wang, Q.; Li, Z.; Zhao, R.; Sun, Q. Investigating the Ground Deformation and Source Model of the Yangbajing Geothermal Field in Tibet, China with the WLS InSAR Technique. Remote Sens. 2016, 191. [CrossRef]

12. Hsieh, Y.; Chan, Y.; Hu, J. Digital Elevation Model Differencing and Error Estimation from Multiple Sources: A Case Study from the Meiyuan Shan Landslide in Taiwan. Remote Sens. 2016, 199. [CrossRef]

13. Zhu, S.; Xu, C.; Wen, Y.; Liu, Y. Interseismic Deformation of the Altyn Tagh Fault Determined by Interferometric Synthetic Aperture Radar (InSAR) Measurements. Remote Sens. 2016, 233. [CrossRef]

14. Vetrivel, A.; Gerke, M.; Kerle, N.; Vosselman, G. Identification of Structurally Damaged Areas in Airborne Oblique Images Using a Visual-Bag-of-Words Approach. Remote Sens. 2016, 231. [CrossRef]

15. Bardi, F.; Raspini, F.; Ciampalini, A.; Kristensen, L.; Rouyet, L.; Lauknes, T.; Frauenfelder, R.; Casagli, N. Space-Borne and Ground-Based InSAR Data Integration: The Åknes Test Site. Remote Sens. 2016, 237. [CrossRef]

16. Liu, P.; Li, Q.; Li, Z.; Hoey, T.; Liu, G.; Wang, C.; Hu, Z.; Zhou, Z.; Singleton, A. Anatomy of Subsidence in Tianjin from Time Series InSAR. Remote Sens. 2016, 266. [CrossRef]

17. Ma, Y.; Chen, F.; Liu, J.; He, Y.; Duan, J.; Li, X. An Automatic Procedure for Early Disaster Change Mapping Based on Optical Remote Sensing. Remote Sens. 2016, 272. [CrossRef]

18. Yang, C.; Zhang, Q.; Xu, Q.; Zhao, C.; Peng, J.; Ji, L. Complex Deformation Monitoring over the Linfen-Yuncheng Basin (China) with Time Series InSAR Technology. Remote Sens. 2016, 284. [CrossRef]

19. Watanabe, M.; Thapa, R.; Shimada, M. Pi-SAR-L2 Observation of the Landslide Caused by Typhoon Wipha on Izu Oshima Island. Remote Sens. 2016, 282. [CrossRef]

20. Plank, S.; Twele, A.; Martinis, S. Landslide Mapping in Vegetated Areas Using Change Detection Based on Optical and Polarimetric SAR Data. Remote Sens. 2016, 307. [CrossRef]

21. Solaro, G.; De Novellis, V.; Castaldo, R.; De Luca, C.; Lanari, R.; Manunta, M.; Casu, F. Coseismic Fault Model of Mw 8.32015 Illapel Earthquake (Chile) Retrieved from Multi-Orbit Sentinel1-A DInSAR Measurements. Remote Sens. 2016, 323. [CrossRef] 
22. Bai, L.; Jiang, L.; Wang, H.; Sun, Q. Spatiotemporal Characterization of Land Subsidence and Uplift (2009-2010) over Wuhan in Central China Revealed by TerraSAR-X InSAR Analysis. Remote Sens. 2016, 350. [CrossRef]

23. Xu, B.; Li, Z.; Feng, G.; Zhang, Z.; Wang, Q.; Hu, J.; Chen, X. Continent-Wide 2-D Co-Seismic Deformation of the $2015 \mathrm{Mw}$ 8.3 Illapel, Chile Earthquake Derived from Sentinel-1A Data: Correction of Azimuth Co-Registration Error. Remote Sens. 2016, 376. [CrossRef]

24. Ji, L.; Xu, J.; Zhao, Q.; Yang, C. Source Parameters of the 2003-2004 Bange Earthquake Sequence, Central Tibet, China, Estimated from InSAR Data. Remote Sens. 2016, 516. [CrossRef]

25. Li, Y.; Jiang, W.; Zhang, J.; Luo, Y. Space Geodetic Observations and Modeling of 2016 Mw 5.9 Menyuan Earthquake: Implications on Seismogenic Tectonic Motion. Remote Sens. 2016, 519. [CrossRef]

26. Trasatti, E.; Tolomei, C.; Pezzo, G.; Atzori, S.; Salvi, S. Deformation and Related Slip Due to the 2011 Van Earthquake (Turkey) Sequence Imaged by SAR Data and Numerical Modeling. Remote Sens. 2016, 532. [CrossRef]

27. Wang, C.; Mao, X.; Wang, Q. Landslide Displacement Monitoring by a Fully Polarimetric SAR Offset Tracking Method. Remote Sens. 2016, 624. [CrossRef]

28. Liu, Y.; Xu, C.; Li, Z.; Wen, Y.; Chen, J.; Li, Z. Time-Dependent Afterslip of the 2009 Mw 6.3 Dachaidan Earthquake (China) and Viscosity beneath the Qaidam Basin Inferred from Postseismic Deformation Observations. Remote Sens. 2016, 649. [CrossRef]

29. Xu, B.; Feng, G.; Li, Z.; Wang, Q.; Wang, C.; Xie, R. Coastal Subsidence Monitoring Associated with Land Reclamation Using the Point Target Based SBAS-InSAR Method: A Case Study of Shenzhen, China. Remote Sens. 2016, 652. [CrossRef]

30. Sun, L.; Muller, J. Evaluation of the Use of Sub-Pixel Offset Tracking Techniques to Monitor Landslides in Densely Vegetated Steeply Sloped Areas. Remote Sens. 2016, 659. [CrossRef]

31. De Novellis, V.; Castaldo, R.; Lollino, P.; Manunta, M.; Tizzani, P. Advanced Three-Dimensional Finite Element Modeling of a Slow Landslide through the Exploitation of DInSAR Measurements and in Situ Surveys. Remote Sens. 2016, 670. [CrossRef]

32. Zhang, Y.; Wu, H.; Kang, Y.; Zhu, C. Ground Subsidence in the Beijing-Tianjin-Hebei Region from 1992 to 2014 Revealed by Multiple SAR Stacks. Remote Sens. 2016, 675. [CrossRef]

33. Zhou, G.; Yue, T.; Shi, Y.; Zhang, R.; Huang, J. Second-Order Polynomial Equation-Based Block Adjustment for Orthorectification of DISP Imagery. Remote Sens. 2016, 680. [CrossRef]

34. Bonì, R.; Pilla, G.; Meisina, C. Methodology for Detection and Interpretation of Ground Motion Areas with the A-DInSAR Time Series Analysis. Remote Sens. 2016, 686. [CrossRef]

35. Xie, S.; Duan, J.; Liu, S.; Dai, Q.; Liu, W.; Ma, Y.; Guo, R.; Ma, C. Crowdsourcing Rapid Assessment of Collapsed Buildings Early after the Earthquake Based on Aerial Remote Sensing Image: A Case Study of Yushu Earthquake. Remote Sens. 2016, 759. [CrossRef]

36. Fernández, T.; Pérez, J.; Cardenal, J.; Gómez, J.; Colomo, C.; Delgado, J. Analysis of Landslide Evolution Affecting Olive Groves Using UAV and Photogrammetric Techniques. Remote Sens. 2016, 837. [CrossRef]

37. Cignetti, M.; Manconi, A.; Manunta, M.; Giordan, D.; De Luca, C.; Allasia, P.; Ardizzone, F. Taking Advantage of the ESA G-POD Service to Study Ground Deformation Processes in High Mountain Areas: A Valle d'Aosta Case Study, Northern Italy. Remote Sens. 2016, 852. [CrossRef]

38. Cooner, A.; Shao, Y.; Campbell, J. Detection of Urban Damage Using Remote Sensing and Machine Learning Algorithms: Revisiting the 2010 Haiti Earthquake. Remote Sens. 2016, 868. [CrossRef]

39. Zhou, W.; Li, S.; Zhou, Z.; Chang, X. InSAR Observation and Numerical Modeling of the Earth-Dam Displacement of Shuibuya Dam (China). Remote Sens. 2016, 877. [CrossRef]

40. Qu, T.; Lu, P.; Liu, C.; Wu, H.; Shao, X.; Wan, H.; Li, N.; Li, R. Hybrid-SAR Technique: Joint Analysis Using Phase-Based and Amplitude-Based Methods for the Xishancun Giant Landslide Monitoring. Remote Sens. 2016, 874. [CrossRef]

41. Gong, L.; Wang, C.; Wu, F.; Zhang, J.; Zhang, H.; Li, Q. Earthquake-Induced Building Damage Detection with Post-Event Sub-Meter VHR TerraSAR-X Staring Spotlight Imagery. Remote Sens. 2016, 887. [CrossRef]

42. Ding, C.; Feng, G.; Li, Z.; Shan, X.; Du, Y.; Wang, H. Spatio-Temporal Error Sources Analysis and Accuracy Improvement in Landsat 8 Image Ground Displacement Measurements. Remote Sens. 2016, 937. [CrossRef] 
43. Ma, C.; Cheng, X.; Yang, Y.; Zhang, X.; Guo, Z.; Zou, Y. Investigation on Mining Subsidence Based on Multi-Temporal InSAR and Time-Series Analysis of the Small Baseline Subset-Case Study of Working Faces 22201-1/2 in Bu'ertai Mine, Shendong Coalfield, China. Remote Sens. 2016, 951. [CrossRef]

44. Caló, F.; Notti, D.; Galve, J.; Abdikan, S.; Görüm, T.; Pepe, A.; Balik Şanli, F. DInSAR-Based Detection of Land Subsidence and Correlation with Groundwater Depletion in Konya Plain, Turkey. Remote Sens. 2017, 83. [CrossRef]

45. Tomás, R.; Li, Z. Earth Observations for Geohazards: Present and Future Challenges. Remote Sens. 2017, 194. [CrossRef]

(C) 2018 by the author. Licensee MDPI, Basel, Switzerland. This article is an open access article distributed under the terms and conditions of the Creative Commons Attribution (CC BY) license (http://creativecommons.org/licenses/by/4.0/). 